\title{
Geographical variation in relative risks associated with cold waves in Spain: The need for a cold wave prevention plan
}

\author{
R. Carmona a,*, J. Díaz ${ }^{\text {a }}$, I.J. Mirón ${ }^{\text {b }}$, C. Ortíz a , I. León ${ }^{\text {c }}$ C. Linares ${ }^{\text {a }}$ \\ a National School of Public Health, Carlos III Institute of Health, Madrid, Spain \\ b Torrijos Public Health District, Castile-La Mancha Regional Health E' Social Affairs Authority (Consejería de Sanidad y Asuntos Sociales de Castilla-La Mancha), Torrijos, Toledo, Spain \\ c National Center of Epidemiology, Carlos III Institute of Health, Madrid, Spain
}

\section{A R T I C L E I N F O}

\section{Article history:}

Received 11 November 2015

Received in revised form 17 December 2015

Accepted 19 December 2015

Available online 29 December 2015

\section{Keywords:}

Cold waves

Mortality

Prevention plans

Geographical variation

Relative risks

\begin{abstract}
A B S T R A C T
In general, there are few studies that analyse the impact of low temperatures on mortality and fewer still that use cold-wave-definition thresholds based on epidemiological and non-climatological criteria. Such a threshold definition, which took into account population features such as socio-economic and demographic characteristics, made it possible for a specific threshold temperature to be obtained for each of Spain's 52 provincial capitals in this study. Using generalised linear models with the Poisson regression link, and controlling for trend, autocorrelations and seasonalities of the series, and influenza epidemics, we obtained the impact of low temperatures on mortality in each provincial capital by calculating the relative risks (RRs) and attributable risks (ARs) for natural as well as circulatory and respiratory causes. The study showed higher minimum temperature thresholds in coastal areas, and an overall impact of cold on mortality in Spain due to natural causes RR $=1.13$ (95\% CI: 1.11-1.16), circulatory causes $\mathrm{RR}=1.18$ (95\% CI: $1.15-1.22)$ and respiratory causes $\mathrm{RR}=1.24$ (95\% CI: $1.20-$ 1.29) slightly greater than that obtained to date for heat. From a public health standpoint, there is a need for specific cold wave prevention plans at a regional level which would enable mortality attributable to low temperatures to be reduced. These plans have shown themselves to be effective in decreasing heat-related mortality, and we feel that they are essential for reducing cold-related effects on morbidity and mortality.
\end{abstract}

(C) 2015 Elsevier Ltd. All rights reserved.

\section{Introduction}

In contrast to the high number of studies which have assessed the impact that heat waves have on population mortality and morbidity, there are relatively few which have focused on extremely low temperatures (Montero et al., 2010; Díaz et al., 2005; Donaldson et al., 2001; The Eurowinter Group, 1997), despite the fact that their impact on mortality represents a public health threat of an importance comparable to that of heat waves (Linares et al., 2015b; Kysely et al., 2009). Indeed, some studies undertaken in the United Kingdom, Australia and The Netherlands even indicate that cold-related deaths are of an order of magnitude greater than those related to heat (Vardoulakis et al., 2014; Huynen et al., 2001), with an effect of low temperatures which, at a global level, is 20 times, and in the case of Spain, 5 times greater than that of heat (Gasparrini et al., 2015b). One study conducted in 14 European countries, indicated that Spain suffers from the second highest rate of excess winter mortality $(21 \%, \mathrm{CI}=19 \%$ to $23 \%)$ after Portugal ( $28 \%, \mathrm{CI}=25 \%$ to $31 \%$ ) (Healy, 2003). Part of the aetiology of the excess mortality observed after exceptionally cold days is known

* Corresponding author at: National School of Public Health, Carlos III Institute of Health, Avda., Monforte de Lemos, 5, 28029, Madrid, Spain.

E-mail address: rocio.carmona@isciii.es (R. Carmona). to be of an infectious nature (Kysely et al., 2009), due to the presence or absence of a pathogenic agent, whose ability to spread is, in turn, favoured by this selfsame drop in temperatures (Hajat and Haines, 2002). Specifically, influenza is the main infectious agent that is associated with winter mortality (Glezen, 1982). The infection of influenza virus is estimated to cause $250,000-500,000$ deaths worldwide every year (WHO, 2014). The actual impact of influenza in overall mortality is difficult to estimate, since deaths due to influenza are usually attributed to different pathological processes. Therefore, the mortality associated with influenza is estimated indirectly by models that calculate the excess of deaths during seasonal influenza seasons, above the base line mortality in the absence of virus circulation (Rizzo et al., 2007; Thompson et al., 2009; López-Cuadrado et al., 2012; León-Gómez et al., 2015). In Spain, the annual rate of excess of deaths by all causes attributed to influenza in the group of age over 64 is estimated in the range of 5-77 deaths/100,000 inhabitants depending on the influenza epidemic considerate (León-Gómez et al., 2015). In the variation of the magnitude of the estimated rates can play an important role both the circulating influenza strain (Thompson et al., 2009; León-Gómez et al., 2015), as an interaction with low temperatures coinciding with peaks of maximum influenza activity (Jaakkola et al., 2014; Nielsen et al., 2011). Also, it's necessary to consider other respiratory infections as possible factors in the excess winter mortality (Matias et al., 2014). 
Cold waves tend to be associated with mortality over a prolonged period (Alberdi et al., 1998; Braga et al., 2001), thereby making it more complicated to establish cause-effect relationships. Added to this is the existing lack of uniformity in the definition of a cold wave. A systematic review conducted until 2013 (Ryti et al., 2015) indicated that in most studies cold waves were statistically defined on the basis of a frequency distribution (e.g., 1st-3rd percentiles) as a set of consecutive days with extreme temperatures, and found a positive association between cold waves and mortality due to all and non-accidental causes, cardiovascular diseases and respiratory diseases, as well as increased morbidity. Cold temperatures are associated with increased occurrence of respiratory tract infections (Makinen et al., 2009), respiratory diseases (Clinch and Healy, 2000; Monteiro et al., 2013), excess cardiovascular-disease mortality and morbidity (Urban et al., 2014; Kysely et al., 2009; Davidkovova et al., 2014), and cardiac arrest deaths (Medina-Ramon et al., 2006). Cold exposure is a trigger factor for certain diseases and can contribute to aggravation of prevailing chronic diseases (Rytkonen et al., 2005).
Furthermore, the trend observed across a 34-year period of analysis in Castile-La Mancha (Spain) (Linares et al., 2015a), which in itself confers an important degree of temporal representativeness, indicates that cold waves have not been accompanied by a rise in mean winter minimum temperatures and have been constant in intensity and number of days. This is in line with other studies which, in the context of climate change, indicate there are climate models which predict that extreme cold weather events are likely to occur over continental European areas, and other middle- and high-latitude regions, under 21stcentury warming scenarios (Kodra et al., 2011). There are very few studies which forecast possible cold-related impacts on the basis of climate models (Vardoulakis et al., 2014), and these assume that the impact of cold on mortality will remain constant over the envisaged prediction period and that it is temperatures that will change (Linares et al., 2015a). Moreover, there has been a shift in the cold-wave pattern, with a decrease in the month of November and a substantial increase in intensity in the month of December (Linares et al., 2015a), a finding that is in line with what has been observed elsewhere in Europe, consisting of a prolongation of summer months and a more delayed, yet more

Table 1

Descriptive statistics of mortality due to natural, respiratory and circulatory causes and minimum temperature ( ${ }^{\circ} \mathrm{C}$ ) in winter months by city in Spain $2000-2009$ period.

\begin{tabular}{|c|c|c|c|c|c|c|c|c|c|c|c|c|c|c|c|c|}
\hline \multirow[t]{2}{*}{ City } & \multicolumn{4}{|c|}{ Natural mortality } & \multicolumn{4}{|c|}{ Respiratory mortality } & \multicolumn{4}{|c|}{ Circulatory mortality } & \multicolumn{4}{|c|}{ Minimum temperature } \\
\hline & Mean & SD & Min & Max & Mean & $\mathrm{SD}$ & Min & Max & Mean & SD & Min & $\operatorname{Max}$ & Mean & SD & Min & $\operatorname{Max}$ \\
\hline A Coruña & 34 & 7 & 14 & 59 & 5 & 3 & 0 & 15 & 13 & 4 & 2 & 29 & 9.1 & 2.8 & 0.6 & 16.8 \\
\hline Albacete & 10 & 3 & 1 & 22 & 1 & 1 & 0 & 9 & 3 & 2 & 0 & 12 & 1.8 & 4.1 & -17.0 & 14.3 \\
\hline Alicante & 39 & 8 & 16 & 72 & 4 & 2 & 0 & 15 & 15 & 4 & 4 & 32 & 8.1 & 3.3 & -2.2 & 19.0 \\
\hline Almería & 12 & 4 & 3 & 29 & 2 & 1 & 0 & 8 & 4 & 2 & 0 & 12 & 10.2 & 2.5 & 0.1 & 18.7 \\
\hline Ávila & 5 & 2 & 0 & 15 & 1 & 1 & 0 & 6 & 2 & 1 & 0 & 7 & 0.5 & 3.8 & -13.2 & 10.8 \\
\hline Badajoz & 19 & 5 & 5 & 38 & 2 & 2 & 0 & 10 & 7 & 3 & 1 & 20 & 5.2 & 4.1 & -7.2 & 17.2 \\
\hline Barcelona & 127 & 20 & 82 & 230 & 16 & 6 & 2 & 49 & 42 & 9 & 19 & 84 & 6.7 & 3.2 & -3.6 & 16.6 \\
\hline Bilbao & 31 & 7 & 13 & 60 & 4 & 2 & 0 & 17 & 10 & 3 & 1 & 27 & 6.4 & 3.9 & -6.0 & 20.7 \\
\hline Burgos & 10 & 3 & 0 & 23 & 1 & 1 & 0 & 7 & 3 & 2 & 0 & 11 & 0.6 & 4.0 & -17.1 & 11.6 \\
\hline Cáceres & 11 & 4 & 2 & 26 & 2 & 1 & 0 & 8 & 4 & 2 & 0 & 17 & 5.3 & 3.6 & -4.6 & 15.6 \\
\hline Cádiz & 25 & 6 & 9 & 48 & 3 & 2 & 0 & 13 & 9 & 3 & 1 & 22 & 11.2 & 2.9 & 0.2 & 19.4 \\
\hline Castellón & 14 & 4 & 3 & 28 & 2 & 1 & 0 & 7 & 5 & 3 & 0 & 15 & 8.1 & 3.1 & -2.0 & 19.0 \\
\hline Ciudad Real & 14 & 4 & 2 & 32 & 2 & 2 & 0 & 14 & 5 & 2 & 0 & 14 & 3.4 & 3.8 & -9.0 & 14.3 \\
\hline Córdoba & 21 & 5 & 7 & 44 & 3 & 2 & 0 & 14 & 8 & 3 & 1 & 20 & 5.8 & 3.8 & -8.2 & 17.5 \\
\hline Cuenca & 5 & 2 & 0 & 14 & 1 & 1 & 0 & 5 & 2 & 1 & 0 & 8 & 1.4 & 3.7 & -11.7 & 12.8 \\
\hline Girona & 16 & 4 & 4 & 35 & 2 & 2 & 0 & 11 & 5 & 2 & 0 & 15 & 2.6 & 4.1 & -10.8 & 16.8 \\
\hline Granada & 22 & 6 & 7 & 48 & 3 & 2 & 0 & 12 & 9 & 3 & 1 & 23 & 3.1 & 3.5 & -10.0 & 15.0 \\
\hline Guadalajara & 5 & 2 & 0 & 15 & 1 & 1 & 0 & 5 & 2 & 1 & 0 & 7 & 0.3 & 4.2 & -12.5 & 12.0 \\
\hline Huelva & 12 & 4 & 2 & 28 & 1 & 1 & 0 & 8 & 5 & 2 & 0 & 15 & 7.7 & 3.4 & -3.2 & 18.4 \\
\hline Huesca & 6 & 3 & 0 & 15 & 1 & 1 & 0 & 6 & 2 & 2 & 0 & 9 & 2.8 & 3.8 & -10.8 & 13.3 \\
\hline Jaén & 17 & 5 & 4 & 46 & 2 & 2 & 0 & 15 & 6 & 3 & 0 & 17 & 7.1 & 3.3 & -7.8 & 18.0 \\
\hline Las Palmas & 18 & 5 & 2 & 35 & 2 & 1 & 0 & 8 & 6 & 3 & 0 & 19 & 16.0 & 2.0 & 10.9 & 22.7 \\
\hline León & 16 & 4 & 4 & 34 & 2 & 2 & 0 & 10 & 5 & 2 & 0 & 14 & 0.5 & 3.7 & -15.0 & 10.4 \\
\hline Logroño & 8 & 3 & 0 & 19 & 1 & 1 & 0 & 6 & 3 & 2 & 0 & 9 & 3.3 & 3.7 & -9.8 & 13.2 \\
\hline Lugo & 14 & 4 & 3 & 33 & 2 & 2 & 0 & 9 & 5 & 2 & 0 & 19 & 2.8 & 4.4 & -10.0 & 15.7 \\
\hline Lleida & 12 & 4 & 2 & 29 & 2 & 1 & 0 & 9 & 4 & 2 & 0 & 14 & 2.6 & 4.0 & -9.8 & 13.5 \\
\hline Madrid & 119 & 16 & 69 & 206 & 19 & 7 & 4 & 54 & 37 & 7 & 16 & 72 & 4.5 & 3.2 & -6.1 & 13.4 \\
\hline Málaga & 33 & 7 & 15 & 58 & 4 & 2 & 0 & 14 & 13 & 4 & 2 & 30 & 9.4 & 3.1 & -0.2 & 20.2 \\
\hline Murcia & 28 & 6 & 11 & 56 & 4 & 2 & 0 & 16 & 11 & 3 & 2 & 22 & 11.4 & 2.6 & 0.4 & 21.8 \\
\hline Ourense & 13 & 4 & 2 & 28 & 2 & 2 & 0 & 9 & 5 & 2 & 0 & 16 & 4.3 & 4.3 & -8.6 & 15.6 \\
\hline Oviedo & 36 & 7 & 17 & 63 & 5 & 3 & 0 & 21 & 13 & 4 & 3 & 29 & 5.5 & 3.4 & -3.7 & 16.5 \\
\hline Pamplona & 15 & 4 & 3 & 31 & 2 & 2 & 0 & 12 & 5 & 2 & 0 & 15 & 2.9 & 3.9 & -11.6 & 16.0 \\
\hline P. Mallorca & 22 & 5 & 7 & 41 & 3 & 2 & 0 & 10 & 8 & 3 & 1 & 21 & 5.7 & 3.9 & -4.0 & 16.8 \\
\hline Pontevedra & 23 & 6 & 6 & 45 & 3 & 2 & 0 & 14 & 8 & 3 & 0 & 20 & 7.1 & 3.3 & -2.0 & 17.0 \\
\hline Salamanca & 11 & 4 & 2 & 26 & 1 & 1 & 0 & 9 & 4 & 2 & 0 & 11 & 0.2 & 4.2 & -12.0 & 12.5 \\
\hline Santander & 16 & 5 & 5 & 38 & 2 & 2 & 0 & 12 & 5 & 2 & 0 & 14 & 6.8 & 3.7 & -5.2 & 20.2 \\
\hline S. C. Tenerife & 19 & 5 & 4 & 38 & 2 & 1 & 0 & 9 & 6 & 3 & 0 & 16 & 16.4 & 1.8 & 11.6 & 22.5 \\
\hline Segovia & 4 & 2 & 0 & 12 & 1 & 1 & 0 & 4 & 1 & 1 & 0 & 8 & 1.7 & 3.8 & -13.2 & 15.4 \\
\hline Sevilla & 43 & 9 & 21 & 80 & 4 & 2 & 0 & 16 & 19 & 5 & 6 & 40 & 8.3 & 3.4 & -3.5 & 18.4 \\
\hline Soria & 3 & 2 & 0 & 12 & 0 & 1 & 0 & 6 & 1 & 1 & 0 & 6 & -0.1 & 3.9 & -13.6 & 10.6 \\
\hline S. Sebastián & 18 & 5 & 4 & 36 & 2 & 2 & 0 & 14 & 6 & 2 & 0 & 16 & 6.9 & 3.6 & -5.6 & 18.0 \\
\hline Tarragona & 17 & 5 & 4 & 39 & 2 & 2 & 0 & 9 & 6 & 2 & 0 & 17 & 7.0 & 3.5 & -2.6 & 18.0 \\
\hline Teruel & 4 & 2 & 0 & 13 & 1 & 1 & 0 & 5 & 2 & 1 & 0 & 7 & -0.9 & 4.3 & -19.0 & 11.2 \\
\hline Toledo & 15 & 4 & 2 & 34 & 2 & 2 & 0 & 12 & 5 & 2 & 0 & 17 & 3.2 & 4.0 & -9.6 & 13.6 \\
\hline Valencia & 63 & 11 & 32 & 114 & 8 & 4 & 1 & 26 & 23 & 5 & 8 & 47 & 8.9 & 3.2 & -1.6 & 18.0 \\
\hline Valladolid & 13 & 4 & 3 & 29 & 2 & 1 & 0 & 10 & 5 & 2 & 0 & 14 & 1.8 & 3.8 & -10.8 & 11.8 \\
\hline Vitoria & 7 & 3 & 0 & 16 & 1 & 1 & 0 & 7 & 2 & 1 & 0 & 10 & 2.2 & 4.0 & -11.5 & 14.6 \\
\hline Zamora & 7 & 3 & 0 & 19 & 1 & 1 & 0 & 6 & 2 & 2 & 0 & 9 & 2.0 & 4.2 & -10.6 & 12.8 \\
\hline Zaragoza & 26 & 6 & 11 & 54 & 3 & 2 & 0 & 14 & 9 & 3 & 1 & 21 & 4.2 & 3.9 & -9.5 & 15.3 \\
\hline
\end{tabular}




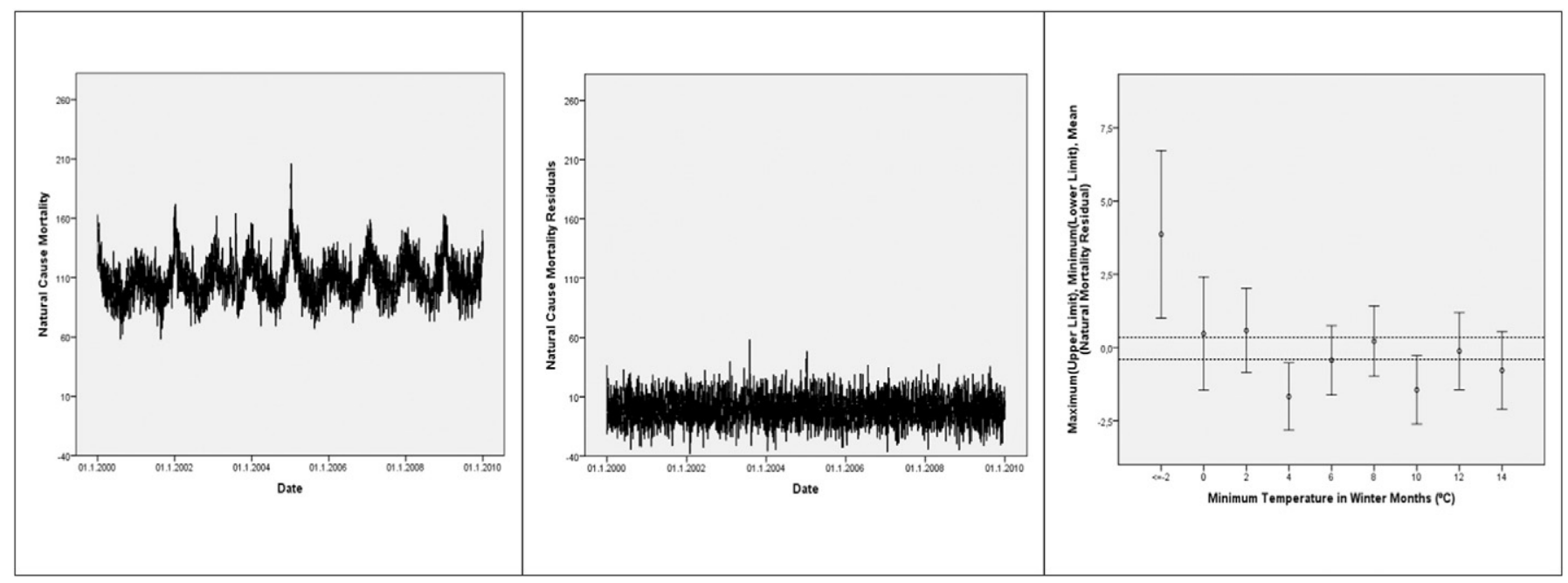

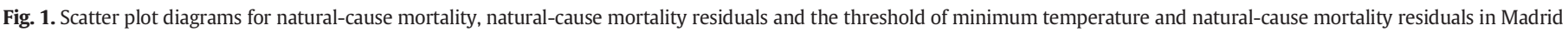
(Spain).

abrupt, onset of winter (Brunetti et al., 2000; WHO, 2007). Currently, however, there are no cold prevention plans in place in the vast majority of European cities, despite the fact that these plans are more effective than heat plans in terms of preventable deaths/day.

Since cold waves are not going to decrease and the population over the age of 65 years is inevitably going to increase (accounting for 38.7\% of the population in 2064 vs. $18.2 \%$ at the present time) (INE, 2014a), specific epidemiological studies focusing on the mortality-temperature relationship will be needed for each study area (Díaz et al., 2015b; Ng et al., 2014).

Accordingly, the designated aim of this study was to ascertain the following for each Spanish provincial capital: firstly, the minimum daily temperature from which there was a significant increase in coldrelated mortality; and secondly, the associated relative risks and attributable risks, along with their geographical distribution. Our analysis extended to increases in cold-related daily mortality due, not only to natural causes, but also to circulatory and respiratory causes.

\section{Methods}

\subsection{Setting}

Spain is the second largest country in Western Europe $\left(504,030 \mathrm{~km}^{2}\right)$, with a total population of 46,507,760 (INE, 2014b). Mainland Spain is bordered to the south and east by the Mediterranean Sea, to the north by France and the Bay of Biscay, and to the north-west and west by the Atlantic Ocean and Portugal. Spanish territory also includes the Balearic Islands in the Mediterranean, the Canary Islands in the Atlantic Ocean off the African coast, and two autonomous enclaves in North Africa, namely, the cities of Ceuta and Melilla. The country is divided into 17 Autonomous Regions (Comunidades Autónomas), which are in turn subdivided into Provinces. Some Autonomous Regions were constituted into one provinces and others in eight. Due to Spain's geographical situation and conditions, the climate is extremely diverse and can be roughly classified into the following five main

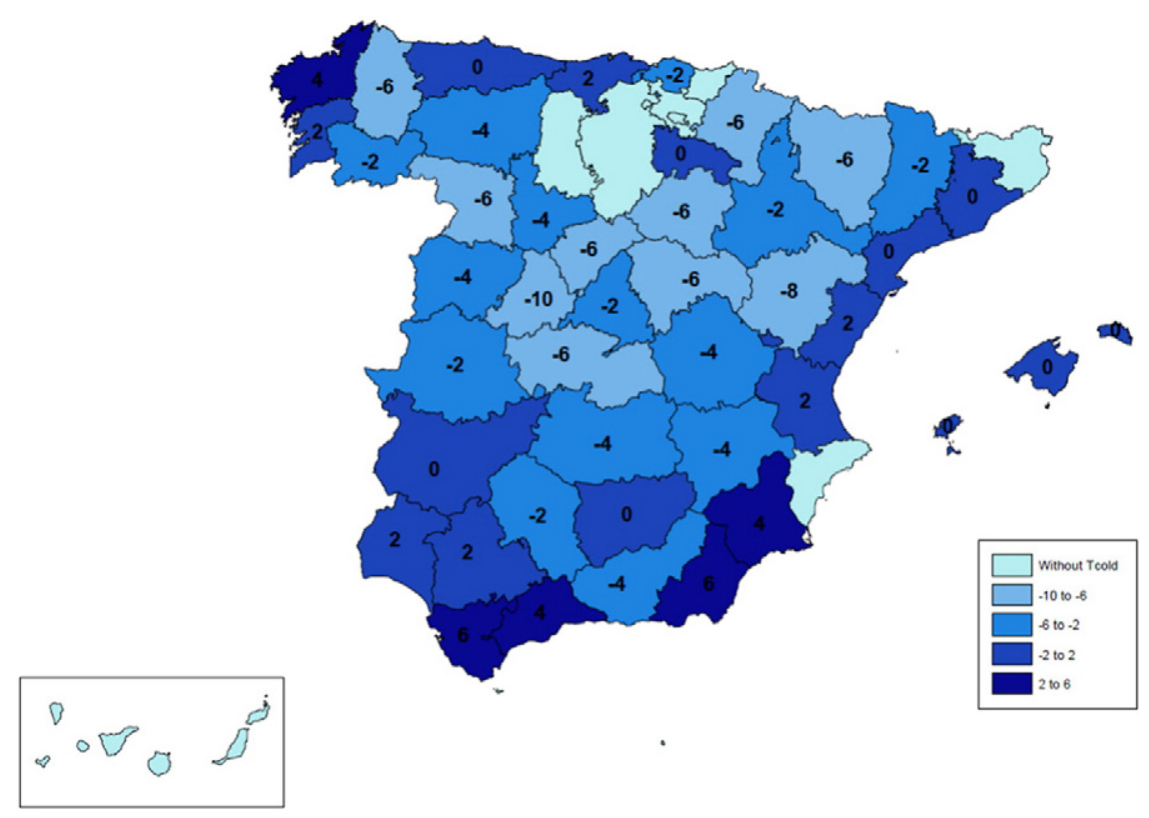

Fig. 2. Minimum temperature threshold's $\left({ }^{\circ} \mathrm{C}\right.$ ) for daily mortality attributable to cold due to natural causes corresponding to $2000-2009$ period in Spain. 


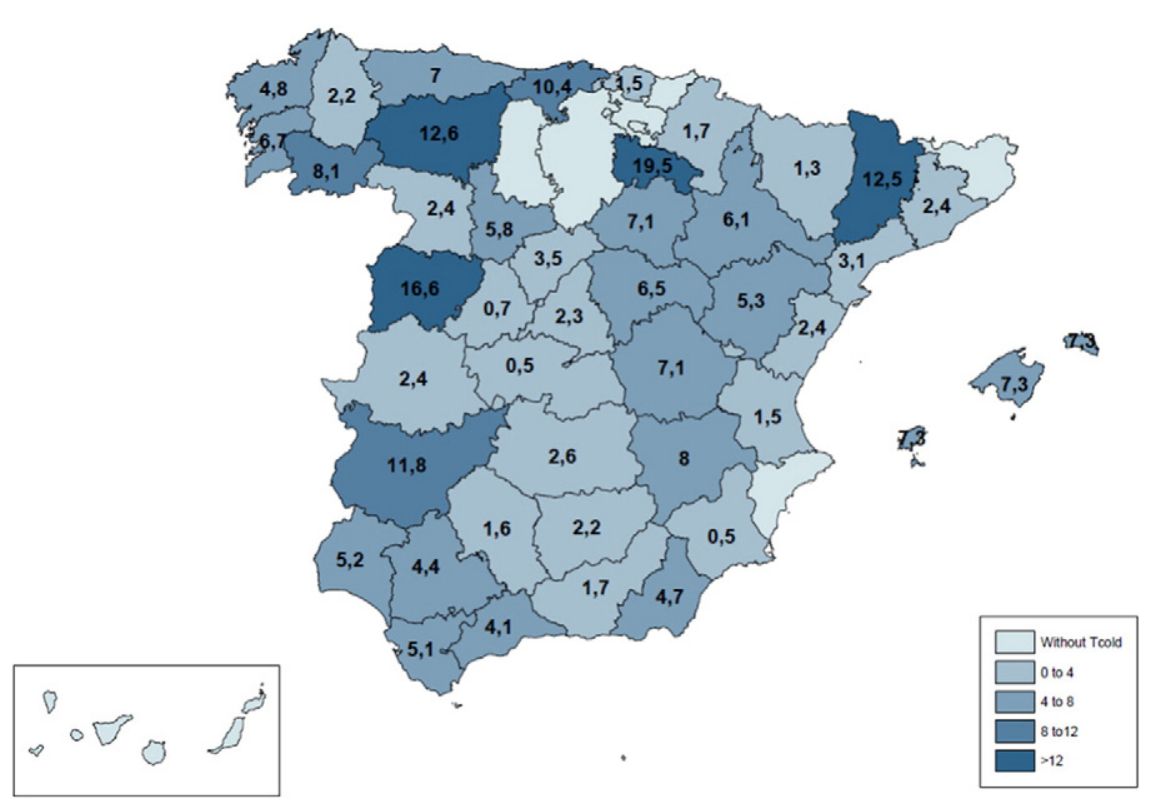

Fig. 3. Percentiles of the series of minimum daily temperatures associated with cold-mortality due to natural causes in the period 2000-2009 in Spain.

zones: a Mediterranean climate extending along the southern and eastern coasts up to the Pyrenees; a semi-arid Mediterranean climate in the south-east; a continental Mediterranean climate in the inland areas of mainland Spain; an oceanic climate in the north-west and along the coastal strip bordering the Bay of Biscay; and a sub-tropical climate in the Canary Islands (Prieto et al., 2004).

\subsection{Data}

As the health variable, we used data on daily mortality due to natural causes (International Classification of Diseases 10th Revision (ICD-10): A00-R99), circulatory causes (ICD-10: I00-I99) and respiratory causes (ICD-10: J00-J99), in each of Spain's 52 provincial capitals and in towns and cities of over 10,000 inhabitants, across the period 1 January 2000 to 31 December 2009. The daily mortality data were obtained from microfiches containing death data broken down by cause of death and supplied under a data-loan agreement by the National Statistics Institute to the Carlos III Institute of Health (Ministry of Economic Affairs \& Competitiveness/Ministerio de Economía y Competitividad), for the purpose of undertaking a "Study of influenza-related mortality in Spain". As this study was ecological in design, it was exempt from approval by a research ethics panel.

The minimum daily temperature data for this period corresponded to the records kept by the respective meteorological observatories in the various provincial capitals, and were furnished by the State Meteorological Agency (Agencia Estatal de Meteorología/AEMET), except in the case of Palencia for which there were no records for the period. The meteorological observatories were located at sites established by the State Meteorological Agency (www.aemet.es).

Data on the weekly influenza incidence rate, including lags until day 15 (influenza rate: lags 1-15), were obtained from the System Sentinel Influenza Surveillance in Spain (http://vgripe.isciii.es/gripe/inicio.do), part of the National Epidemiological Surveillance Network.

The international literature contains different approaches to determining threshold temperatures (Basu and Samet, 2002; Tong et al., 2010; Gasparrini et al., 2015a). For the purposes of our analysis, however, we applied the methodology used in the following papers: Montero et al. (2010), Miron et al. (2012), Mirón et al. (2015), Roldán et al. (2014), and Linares et al. (2015b). The advantage of working with residuals rather than daily mortality is that, after modelling, residuals display neither trend nor periodicities (both of which are inherent in daily mortality), with the result that any associations found will therefore show a genuine causal mortality-temperature relationship from a statistical standpoint $(\mathrm{p}<0.05)$

We first fitted a univariate autoregressive integrated moving average (ARIMA) model (Box et al., 1994) for daily mortality in each of the 52 provincial capitals, which allowed us to obtain the residuals of the mortality series. From the ARIMA models we obtained the fit and the (upper and lower) confidence intervals corresponding to this fit. Mortality residuals are the difference between the raw mortality and the fit. We then proceeded to plot the following on a scatterplot diagram: the mean value of the mortality series residuals on the same day (vertical axis); the minimum daily temperatures at $2{ }^{\circ} \mathrm{C}$ intervals (horizontal axis), and their corresponding 95\% confidence intervals (CIs) (upper and lower limits of the CI: UL and LL respectively); and the $95 \%$ CIs of the mean of the residuals for the entire study period (shown by parallel broken lines). When mortality residuals are shown on a scatterplot diagram with the minimum temperature data, the deviations detected correspond to real mortality anomalies. The temperature from which the mortality residuals increased significantly vis-à-vis the mean would thus be the threshold temperature.

The impact of extreme temperature on mortality was quantified, using generalised linear model (GLM) methodology, with the Poisson regression link. This methodology allows for calculation of the relative risks (RRs) associated with increases in the environmental variable, in this case temperature. Based on the RR, we then calculated the attributable risk (AR) associated with this increase via the following equation (Coste and Spira, 1991):

$\mathrm{AR}=[(\mathrm{RR}-1) / \mathrm{RR}] \times 100$.

On fitting the model, we controlled: firstly, for seasonalities of an annual, six-monthly and quarterly nature, using the sine and cosine functions with these same periodicities; and secondly, for trend and the possible autoregressive nature of the series.

To consider the effect of a cold wave through minimum daily temperatures (Tmin), we respectively created the variables Tcold, defined on the basis of the previously calculated mortality threshold temperatures (Tthreshold) as those on which the minimum daily temperature 


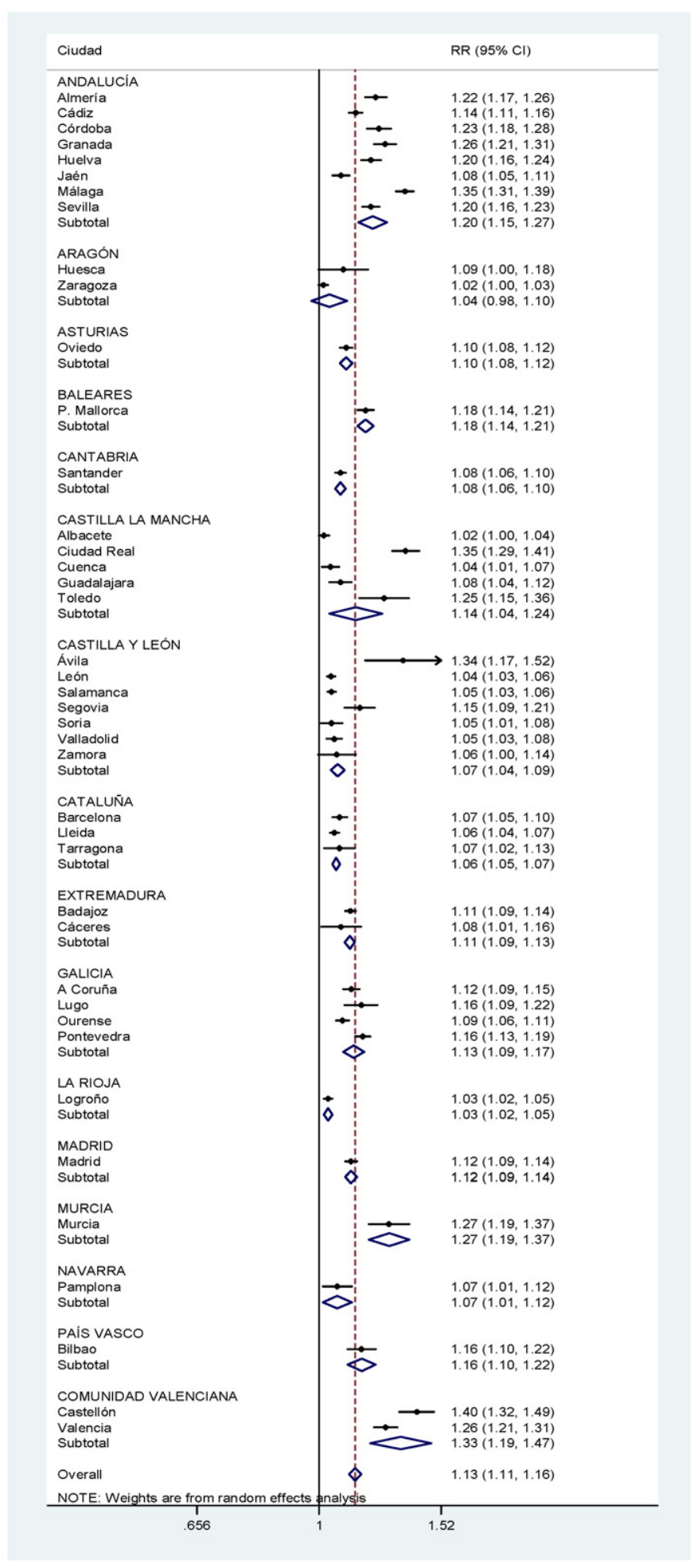

Fig. 4. Relative risks (RR) calculated for decrement of $1{ }^{\circ} \mathrm{C}$ under the threshold temperature associated to cold-waves due to natural-causes mortality in Spain.

failed to exceed Tthreshold (Díaz et al., 2005):

$\begin{array}{ll}\text { Tcold }=0 & \text { if Tmin }>\text { Tthreshold } \\ \text { Tcold }=\text { Tthreshold }- \text { Tmin } & \text { if Tmin } \leq \text { Tthreshold }\end{array}$

Given that the effect of a cold wave on mortality may not be immediate, the following lagged variables were calculated: Tcold (lag 1), which takes into account the effect of the temperature on day "d" on mortality, one day later, “d + 1"; Tcold (lag 2), which takes into account the effect of the temperature on day "d" on mortality, two days later, " $d+2$ "; and so on successively. The number of lags were selected on the basis of the literature, which establishes that the effect of cold may also have effects in the medium term (Tcold: lags 1-13) (Alberdi et al., 1998). Lags until day 15 were included for the weekly influenza incidence rate (lags 1-15). The trend was controlled through a variable in the database that counts along the period: this variable starts on the first day of the series and continues to the end of the series, such that it is 1 on 1st January 2000 and 2963 on 31st December 2009.

Significant variables (Tcold and its corresponding lags and the control variables) were determined using the Step-Step procedure, beginning with the model that included all the explanatory variables, and gradually eliminating those which individually displayed least statistical significance, with the process being reiterated until all the variables included were significant at $\mathrm{p}<0.05$. Modelling was performed for the winter months (November to March). These RRs were calculated for both natural-cause and circulatory- and respiratory-cause mortality. The increases in the RRs and ARs obtained refer to increases for each ${ }^{\circ} \mathrm{C}$ that the minimum daily temperature fell below the threshold temperature. The RRs for each province obtained by Poisson regression were combined using a random-effects meta-analysis, which incorporates an estimate of between-study variation (heterogeneity) in the weighting (Sterne, 2009) to obtain a measurement of RR (95\% CI) at both a regional and national level.

All analyses were performed using the IBM SPSS Statistics v22 and STATA v11.2 statistical software programmes, with the ArcGIS v10.2.2 software programme being used for geographical representation.

\section{Results}

Table 1 shows the descriptive statistics in the winter months for the dependent and independent variables used in this study. Teruel was the city with the lowest mean minimum temperature, $-0.9^{\circ} \mathrm{C}$, and S. C. Tenerife had the highest value, $16.4{ }^{\circ} \mathrm{C}$.

By way of example, Fig. 1 shows, firstly a scatter-plot diagram for raw natural-cause mortality, secondly, the residuals of the same mortality series after being pre-whitened with the ARIMA model, and lastly, the mortality threshold temperature obtained for the city of Madrid. As can be seen, the definition of a cold wave in Madrid was established for days on which the minimum daily temperature fell below $-2{ }^{\circ} \mathrm{C}$, which was the percentile 2.3 of the minimum temperature series for the winter months of this period, because the daily mortality residuals registered a statistically significant anomalous value.

If the threshold temperature is calculated in this way for each of the 52 provincial capitals (except Palencia for which there were no meteorological data), Fig. 2 is obtained. No threshold or "trigger" cold-wave mortality temperature was obtained for the following provincial capitals, namely, San Sebastian, Vitoria, Burgos, Girona, Alicante, Gran Canaria, Tenerife, Ceuta and Melilla. The threshold temperatures ranged from $-10{ }^{\circ} \mathrm{C}$ in Avila to $6{ }^{\circ} \mathrm{C}$ in Almeria and Cadiz. The percentiles to which the temperatures in Fig. 2 correspond in relation to the minimum daily temperature series for this period are shown in Fig. 3: these ranged from percentile 19.5 in the province of Logroño to percentile 0.5 in the provinces of Murcia and Toledo.

If the RRs associated with an increase of $1{ }^{\circ} \mathrm{C}$ below the cold-wave threshold temperature are calculated for each provincial capital, the results shown in Fig. 4 are obtained. In addition, this figure depicts the RRs for each Autonomous Region and for Spain as a whole. Regions which had no threshold temperatures or those in which cold was not a risk factor are not shown in the figures.

This figure shows that the RRs for provincial capitals ranged from $1.40(1.32-1.49)$ in the case of Castellon to $1.2(1.00-1.04)$ in the case of Albacete and Zaragoza, with these differences proving statistically significant. 


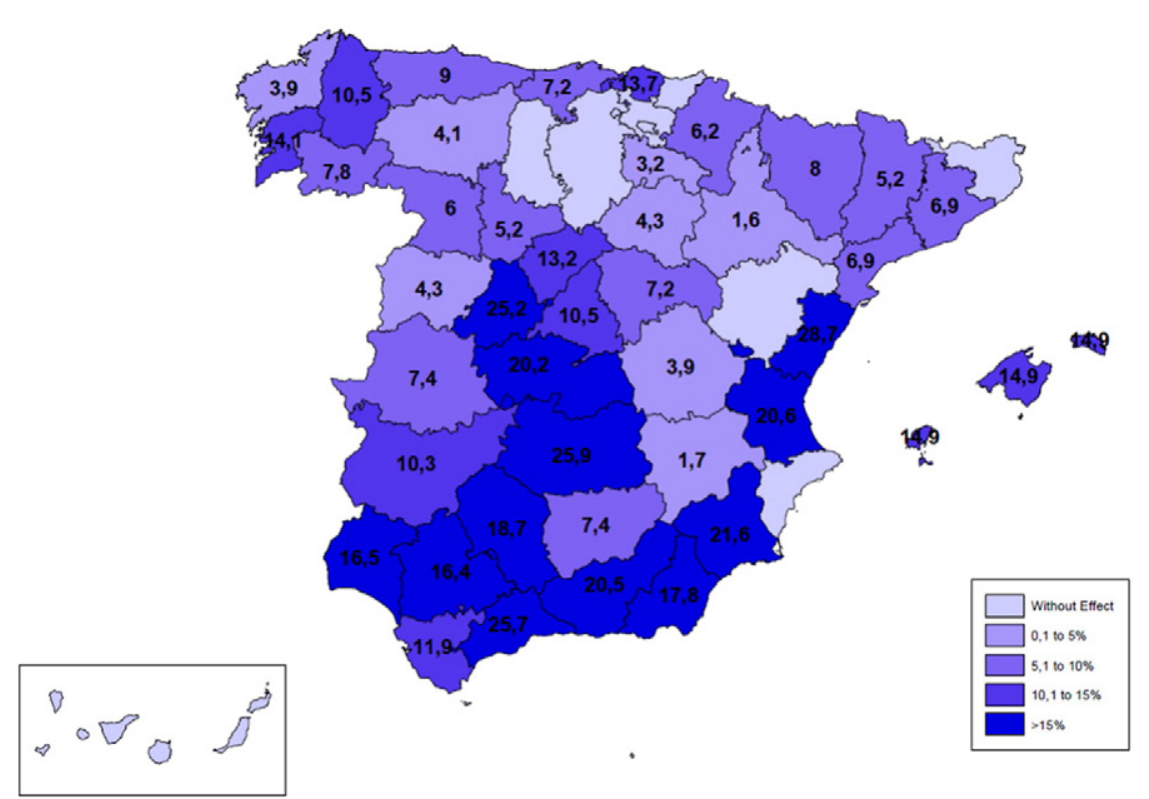

Fig. 5. Attributable risk (\%) associated to cold-waves mortality in Spain in the period 2000-2009.

At a regional level, the values were very similar, both within and as between the respective Autonomous Regions, with the Valencian Region displaying the highest RR, 1.33 (1.19-1.47), and La Rioja displaying the lowest RR, 1.03 (1.02-1.05); once again, these differences proved statistically significant, though in the case of the province of Teruel the effect of cold on mortality failed to display statistically significance.

For Spain overall, the RR was 1.13 (1.11-1.16).

As a general rule, threshold temperatures corresponding to low percentiles were found to be associated with high RRs, whereas threshold temperatures corresponding to high percentiles tended to be accompanied by lower RRs.

Fig. 5 shows the ARs for each provincial capital, which logically coincided with their RR distribution, inasmuch as ARs are calculated on the basis of RRs.

Lastly, Figs. 6 and 7 depict the forest plot resulting from the metaanalysis, showing the RRs of circulatory- and respiratory-cause mortality for each provincial capital, each Autonomous Region and the country as a whole. As will be seen, generally speaking, the effect was greater for respiratory-cause than for circulatory-cause mortality; however, this difference was not statistically significant for Spain as a whole. Likewise, the capitals without cold effects on mortality differed for respiratory (Avila, Jaen, Lugo, Pamplona, Bilbao and Zaragoza) and circulatory causes (Caceres, Huesca, Segovia, Toledo and Zamora). The number of capitals in which there was a cold-related effect for circulatory but not for respiratory causes, was also higher.

\section{Discussion}

This study used minimum daily temperatures associated with coldrelated mortality (Montero et al., 2010, 2012; Miron et al., 2012) to ascertain the threshold temperatures for defining cold waves for each of Spain's provincial capitals across the period 2000-2009, along with their percentiles. In addition, it also measured the impact that minimum temperatures below the established thresholds had on natural-, respiratory- and circulatory-cause mortality in all the above capitals.

The inter-regional variability observed in terms of what would be considered cold-wave mortality threshold temperatures (Fig. 2) and their associated percentiles (Fig. 3) is a sign of a variety of underlying factors, such as adaptation to cold by a given population, socioeconomic and structural differences or divergences in population pyramids, infrastructures adapted to extreme temperatures and inequalities in access to health services (Montero et al., 2012; Naughton et al., 2002;
Nakai et al., 1999; Vandentorren et al., 2006), i.e., differences that are taken into account when threshold temperatures based on epidemiological criteria are considered methodologically. Fig. 2 shows that minimum threshold temperatures are higher in coastal areas, coinciding with those regions that have lower heat wave threshold temperatures (Díaz et al., 2015b). These are regions where home air conditioning and heating arrangements are different to those of other regions with more extreme climates, since they experience milder temperatures throughout the year. Residents in warm regions have fewer physical, social, and behavioural adaptations to low temperatures (Lin et al., 2013), and the effects of cold are thus more significant in warm regions (Langford and Bentham, 1995; Wang et al., 2012) or areas with moderate winter climates (Conlon et al., 2011). Furthermore, "houses in countries with comparatively warm climates all year round tend to lose heat easily, so people find it hard to heat their homes when winter arrives. This is especially true in Portugal, Spain, and Ireland. Conversely, houses in countries with severe climates - such as Scandinavia - have to be thermally efficient to retain warmth" (European Commission).

In terms of cold-threshold time trends, the only studies to use the same methodology were conducted in the Autonomous Region of Castile Mancha, which, for the period 1975-2008, registered a cold wave threshold of $-2{ }^{\circ} \mathrm{C}$ ( 4 th percentile) based on the minimum daily temperature (Linares et al., 2015a; Linares et al., 2015b), while Ciudad Real registered a threshold of $-3{ }^{\circ} \mathrm{C}$ (5th percentile winter months) (Miron et al., 2012) for the period 1990-2003. Using similar methodology, i.e., considering the minimum daily temperature series but establishing the threshold on the basis of the 5 th percentile of this series in the winter months in view of the fact that heterogeneity in the mortality residuals made it impossible for significant thresholds to be determined, the following thresholds were registered for the period 1975-2003: Albacete, $-4.8{ }^{\circ} \mathrm{C}$; Ciudad Real, $-3.4{ }^{\circ} \mathrm{C}$; Cuenca, $-5{ }^{\circ} \mathrm{C}$; Guadalajara, $-5.6{ }^{\circ} \mathrm{C}$; and Toledo, $-3.3{ }^{\circ} \mathrm{C}$ (Montero et al., 2010). Indeed, coldrelated mortality trigger thresholds have also been established for the Madrid region (Díaz et al., 2005; Díaz et al., 2006), where calculation yielded a threshold of $5{ }^{\circ} \mathrm{C}$ for the period $1986-1997$, coinciding with the 5 th percentile of the maximum winter temperature series.

Despite the lack of references with which to compare the thresholds established in this study to those of previous periods, a fall in thresholds was nevertheless in evidence for all the provincial capitals of Castile-La Mancha except Cuenca (period 2000-2009: $-4{ }^{\circ} \mathrm{C}$ vs. $1975-2003$ : $-5{ }^{\circ} \mathrm{C}$ ). This fall may be attributable to differences in threshold definitions, which were based on climatological criteria via the 5 th percentile 


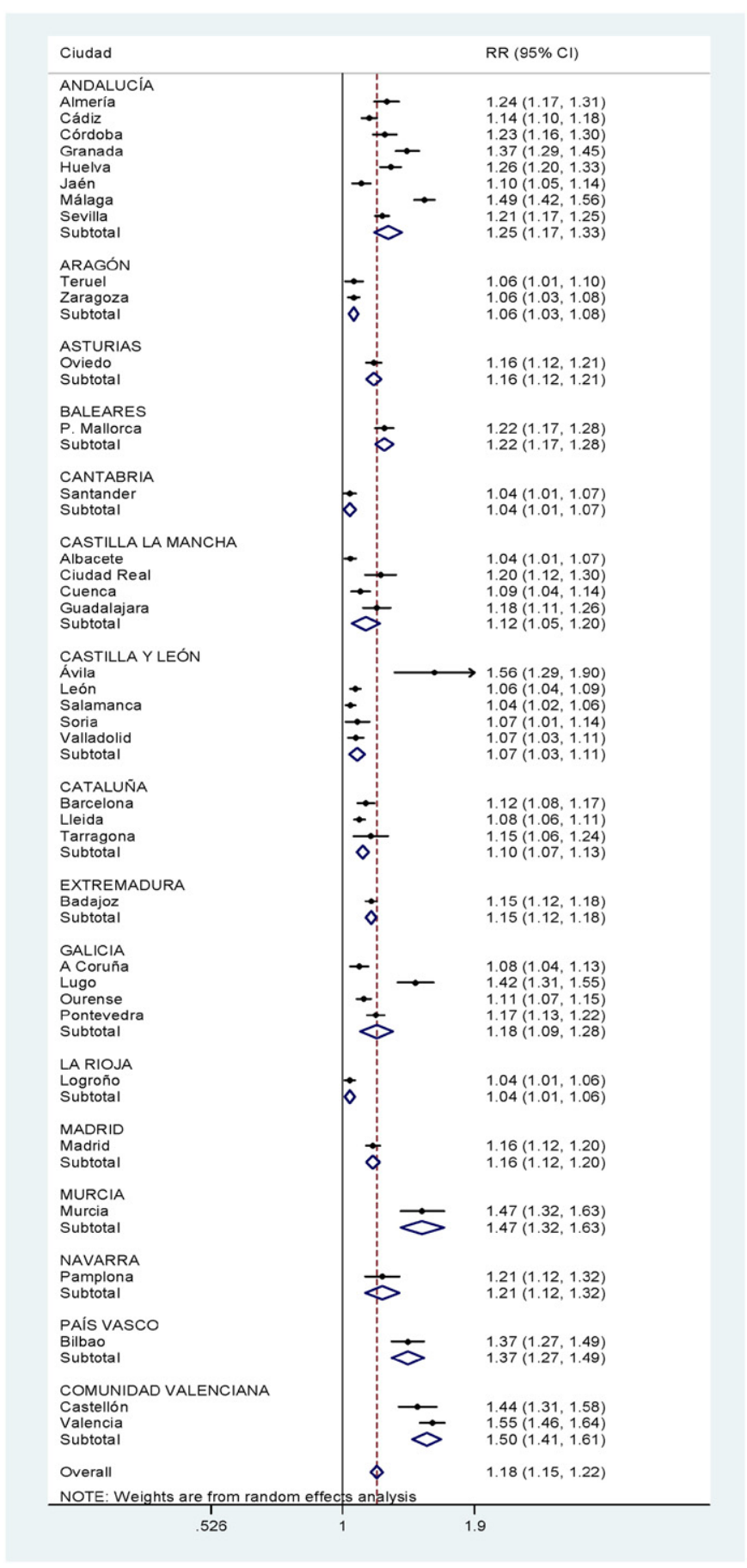

Fig. 6. Relative risks (RR) calculated for decrement of $1{ }^{\circ} \mathrm{C}$ under the threshold temperature associated to cold due to circulatory-causes mortality in Spain.

of the minimum daily temperature series for each provincial capital, and not on epidemiological thresholds, which take into account a far broader range of the underlying factors that influence the different mortality patterns and vary from one region to another, such as socioeconomic conditions and ability to adapt to local climate type (Guo et al., 2014), lifestyle, and population structure.

Threshold temperatures corresponding to low percentiles of minimum winter temperatures were, as in the case of heat (Díaz et al., 2015b), observed to be associated with high RRs, due to the fact that cold-related mortality is distributed over a very short period of days during which temperatures fall below the threshold temperature.

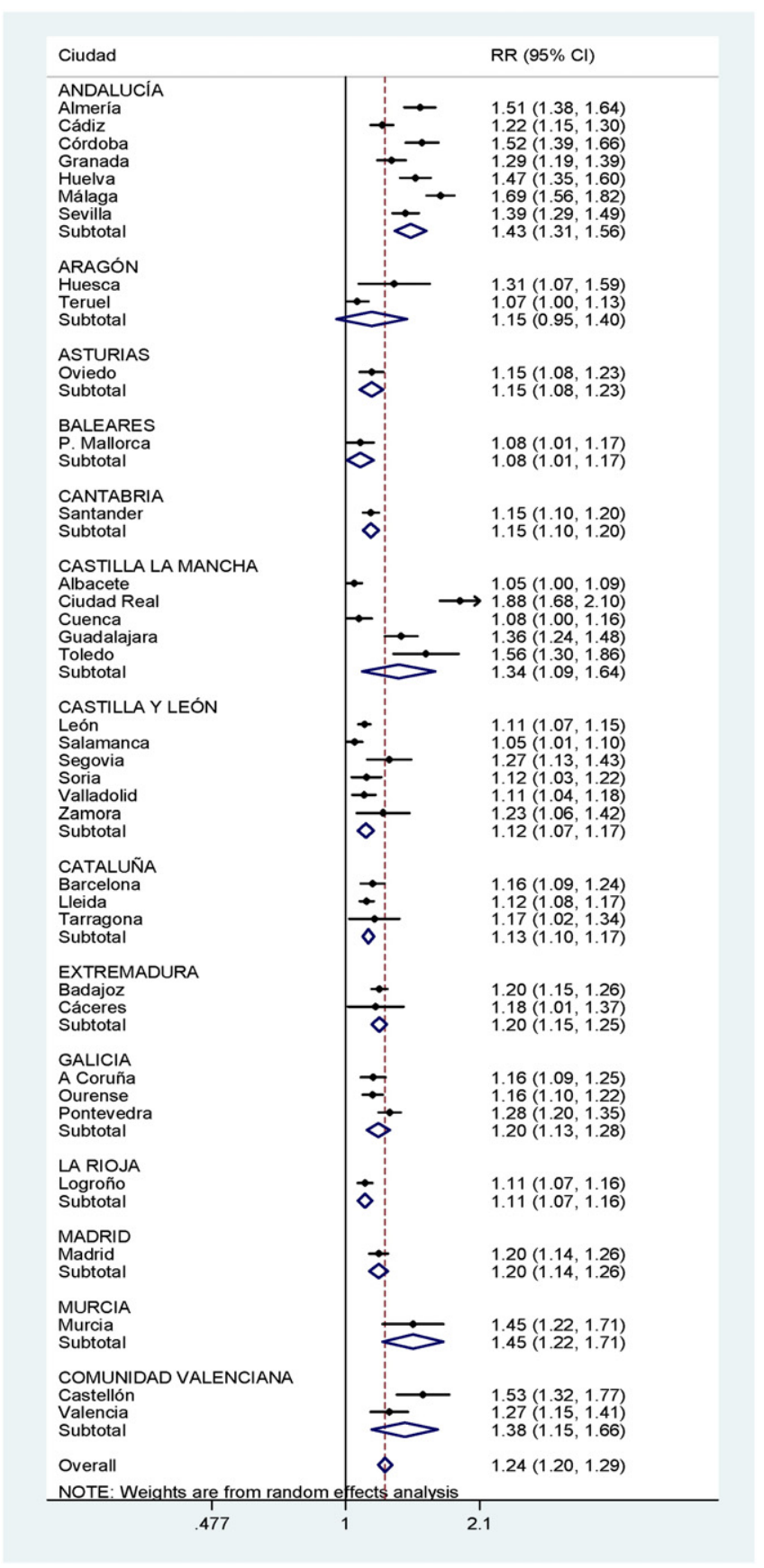

Fig. 7. Relative risks (RR) calculated for decrement of $1{ }^{\circ} \mathrm{C}$ under the threshold temperature associated to cold due to respiratory-causes mortality in Spain.

Teruel was the city with the lowest minimum mean temperature in the winter months, namely, $-0.9^{\circ} \mathrm{C}$, and the provincial capital with the second-lowest minimum cold wave threshold temperature $\left(-8{ }^{\circ} \mathrm{C}\right.$, percentile 5.3) after Avila ( $-10{ }^{\circ} \mathrm{C}$, percentile 0.7$)$. However, cold did not have a significant effect on mortality due to organic causes, though it did on mortality due circulatory and respiratory causes.

Cold shows an overall impact on mortality in Spain due to natural causes $\mathrm{RR}=1.13$ (95\% CI: 1.11-1.16) (Fig. 4), circulatory causes $\mathrm{RR}=1.18(95 \% \mathrm{CI}: 1.15-1.22)$ (Fig. 6$)$ and respiratory causes $\mathrm{RR}=$ 1.24 (95\% CI: 1.20-1.29) (Fig. 7) slightly greater than that observed for heat $\left(\mathrm{RR}_{\text {natural mortality }}=1.11(1.10-1.12), \mathrm{RR}_{\text {circulatory mortality }}=1.11\right.$ $(1.09-1.13), R_{\text {respiratory mortality }}=1.18(1.16-1.21)$ ) (Díaz et al., 2015b). This is a significant impact that has also been observed in other countries (Wang et al., 2014; Lin et al., 2013) and that displays 
values very similar to those obtained in a systematic review and metaanalysis conducted until 2013 without restrictions on type of study or format of report (Ryti et al., 2015), in which cold waves were seen to increase total and non-accidental mortality ( $\mathrm{RR}=1.10 ; 95 \% \mathrm{CI}$ : 1.04 , 1.17), mortality due to cardiovascular diseases ( $\mathrm{RR}=1.11 ; 95 \% \mathrm{CI}$ : $1.03,1.19)$ and mortality due to respiratory diseases ( $R R=1.21 ; 95 \%$ CI: $0.97,1.51)$. The greater impact of cold on respiratory-cause mortality, albeit without statistically significant differences vis-à-vis circulatory-cause mortality, had already been observed in studies undertaken in Castile-La Mancha across the period 1975-2008 $\left(\mathrm{AR}_{\text {respiratory mortality }}=14.7 \% \mathrm{vs}\right.$. $\left.\mathrm{AR}_{\text {circulatory mortality }}=9.6 \%\right)$ (Linares et al., 2015b; Linares et al., 2015a), and during longer lags after cold waves (Huynen et al., 2001; Braga et al., 2001; Wu et al., 2013; Xie et al., 2013). In Finland, the occurrence of respiratory tract infections increased with cold temperatures and lower humidity, and a decrease in temperatures and humidity preceded the onset of such infections (Makinen et al., 2009). Hajat and Haines (2002) observed increased numbers of GP consultations among elderly people, particularly for lower respiratory tract infections, with cold temperatures in the United Kingdom. Many studies have linked cold waves to cardiovascular events. On the one hand, Rocklöv et al. (2011) indicated that exposure to cold mainly raised the risk of cardiovascular deaths, which at younger ages, among men aged $25-59$ years, might be most directly related to occupational exposure (Kysely et al., 2009). On the other hand, acute myocardial infarction mortality, which is due most likely to changes in blood coagulation, results in thrombosis (Davidkovova et al., 2014). With respect to other diseases, Zanobetti et al. (2013), found a higher risk of dying from cold waves among patients with prior disorders of the peripheral nervous system or dementia.

The trend observed between the two periods analysed in Madrid, shows that the effect of cold on mortality has increased appreciably (Díaz et al., 2015a), to the extent of tripling, especially in the over-75 age group, and in the 45-64 and 65-74 age groups, in which the AR doubled in relation to the value reported for the period 1986-1997. Elderly people are potentially more susceptible to the effects of cold spells (Ryti et al., 2015; Medina-Ramon et al., 2006), possibly due to a reduced thermoregulatory capacity combined with a diminished ability to detect changes in body temperature (Mercer, 2003).

With respect to the limitations of this study and any possible resulting biases, the following should be mentioned: firstly, an ecological study such as ours does not permit inferences to be made at the level of individuals, for fear of the ecological fallacy arising as a result of the use of pooled data. Secondly, with reference to the quality and consistency of the data analysed, there might possibly have been poor classification of the cause of mortality. Another possible limitation lies in the representativeness of temperatures which were in all cases recorded in the provincial capital: indeed, there are some previous papers that discuss this very point (Mirón et al., 2006; Roldán et al., 2011). No specific validation was done within the project to assess representativeness of spatial variability in temperature measures, our study suffered from Berkson-type measurement error, between others bias associated to an ecological exposure, as is common in most timeseries studies, which leads to no or little bias but decreases statistically power.

With regard to the non-use of other environmental variables of interest, such as air pressure and relative humidity, these were not included in the analysis owing to their negligible relevance in the temperature-mortality relationship (Barnett et al., 2010; Montero et al., 2012). Insofar as particulate air pollution is concerned, the lack of quality data at a national level rendered their use inadvisable, owing to the risk of introducing instability into the complete series (Linares et al., 2014).

Furthermore, when it comes to methodological limitations, mention should essentially be made of two shortcomings inherent in a statistical method which works with a high number of variables at a 95\% confidence level. The use of low daily numbers of deaths in some cities, generally leads to higher confidence intervals and lower accuracy in findings.

The non-existence of cold prevention plans in Spain means that their effectiveness cannot be established. Even so, the results obtained by us show - just as in the case of heat (Díaz et al., 2015b) - a clear need for their implementation to prevent premature cold-related mortality, considering that even within a climate-change context, cold waves, far from decreasing, are going to continue to occur from time to time (IPCC, 2014). It must also be borne in mind that prevention plans should not be static because, as with heat (Díaz et al., 2015b), thresholds are also not static and factors such as changes in economic cycles can also alter the situation. Accordingly, one has to be continually making projections and changing the risks in time and space for the different regions and populations, each with its respective underlying factors.

Furthermore, studies conducted in Madrid (Spain) (Díaz et al., 2015a) indicate that cold-related mortality is slightly higher than heat-related mortality, a finding that agrees with the results of this study. However, the number of days with cold waves is lower than that of days with heat waves. This means that daily mortality attributable to cold is higher than that due to heat and, in turn, that the possible decrease in daily mortality brought about by the implementation of a cold prevention plan would be greater than that of an equivalent heat prevention plan, thus appreciably increasing the need for the former.

The study outlined above is especially relevant, inasmuch as there are practically no prevention plans implemented anywhere which are scaled down to the regional level described here, with cold-wave definition thresholds being calculated for the different regions in Spain. The results of the impact of cold on daily mortality (similar at the very least to that those seen for heat) render it essential to implement specific prevention plans for low temperatures.

\section{Acknowledgements}

This study was supported by grants: FIS ENPY 1001/13 \& SEPY 1037/ 14 from Spain's Health Research Fund.

\section{References}

Alberdi, J.C., Diaz, J., Montero, J.C., Miron, I., 1998. Daily mortality in Madrid community 1986-1992: relationship with meteorological variables. Eur. J. Epidemiol. 14 (6), 571-578 (Sep).

Barnett, A.G., Tong, S., Clements, A.C.A., 2010. What measure of temperature is the best predictor of mortality? Environ. Res. 110, 604-611.

Basu, R., Samet, J.M., 2002. Relation between elevated ambient temperature and mortality: a review of the epidemiologic evidence. Epidemiol. Rev. 24, 190-202.

Box, G.E., Jenkins, G.M., Reinsel, C., 1994. Time Series Analysis. Forecasting and Control. Prentice Hall, Englewood.

Braga, A.L., Zanobetti, A., Schwartz, J., 2001. The time course of weather-related deaths. Epidemiology 12 (6), 662-667 (Nov).

Brunetti, M., Maugeri, M., Nanny, T., 2000. Variations on temperature and precipitation in Italy from 1986 to 1995. Theor. Appl. Climatol. 65, 165-174.

Clinch, J.P., Healy, J.D., 2000. Housing standards and excess winter mortality. J. Epidemiol. Community Health 54 (9), 719-720 (Sep).

Conlon, K.C., Rajkovich, N.B., White-Newsome, J.L., Larsen, L., O'Neill, M.S., 2011. Preventing cold-related morbidity and mortality in a changing climate. Maturitas 69 (3), 197-202 (Jul).

Coste, J., Spira, A., 1991. Le proportion de cas attributable en Santé Publique: definition(s), estimation(s) et interpretation. Rev. Epidemiol. Sante Publique 51, 399-411.

Davidkovova, H., Plavcova, E., Kyncl, J., Kysely, J., 2014. Impacts of hot and cold spells differ for acute and chronic ischaemic heart diseases. BMC Public Health 14, 480.

Díaz, J., Garcia, R., Lopez, C., Linares, C., Tobias, A., Prieto, L., 2005 Jan. Mortality impact of extreme winter temperatures. Int. J. Biometeorol. 49 (3), 179-183.

Díaz, J., Linares, C., Tobias, A., 2006 Jul. Impact of extreme temperatures on daily mortality in Madrid (Spain) among the 45-64 age-group. Int. J. Biometeorol. 50 (6), 342-348.

Díaz, J., Carmona, R., Mirón, I.J., Ortiz, C., Linares, C.G., 2015a. Comparison of the effects of extreme temperatures on daily mortality in Madrid (Spain), by age group: the need for a cold wave prevention plan. Environ. Res. 143, 186-191.

Díaz, J., Carmona, R., Mirón, IJ., Ortiz, C., León, I., Linares, C., 2015b. Geographical variation in relative risks associated with heat: update of Spain's Heat Wave Prevention Plan. Environ. Int. 85, 273-283.

Donaldson, G.C., Rintamaki, H., Nayha, S., 2001. Outdoor clothing: its relationship to geography, climate, behaviour and cold-related mortality in Europe. Int. J. Biometeorol. 45 (1), 45-51 (Feb)

European Commission. Climate change. http://ec.europa.eu/health/climate_change/ extreme_weather/cold_weather/index_en.htm. 
Gasparrini, A., Guo, Y., Hashizume, M., Kinney, P.L., Petkova, E.P., Lavigne, E., et al., 2015a. Temporal variation in heat-mortality associations: a multicountry study. Environ. Health Perspect. 123 (11), 1200-1207 (Nov).

Gasparrini, A., Guo, Y., Hashizume, M., Lavigne, E., Zanobetti, A., Schwartz, J., et al., 2015b. Mortality risk attributable to high and low ambient temperature: a multicountry observational study. Lancet 386 (9991), 369-375 (Jul 25).

Glezen, W.P., 1982. Serious morbidity and mortality associated with influenza epidemics. Epidemiol. Rev. 4, 25-44.

Guo, Y., Gasparrini, A., Armstrong, B., Li, S., Tawatsupa, B., Tobias, A., et al., 2014. Global variation in the effects of ambient temperature on mortality: a systematic evaluation. Epidemiology 25 (6), 781-789 (Nov).

Hajat, S., Haines, A., 2002. Associations of cold temperatures with GP consultations for respiratory and cardiovascular disease amongst the elderly in London. Int. J. Epidemiol. 31 (4), 825-830 (Aug).

Healy, J.D., 2003. Excess winter mortality in Europe: a cross country analysis identifying key risk factors. J. Epidemiol. Community Health 57 (10), 784-789 (Oct).

Huynen, M.M., Martens, P., Schram, D., Weijenberg, M.P., Kunst, A.E., 2001. The impact of heat waves and cold spells on mortality rates in the Dutch population. Environ. Health Perspect. 109 (5), 463-470 (May).

INE, 2014a. Proyecciones de Población de población (2014-2064) residente en España a 1 de enero. http://www.ine.es/prensa/np870.pdf.

INE, 2014b. Cifras de Población a 1 de enero de 2014. INE (www.ine.es).

IPCC, 2014. In: Pachauri, R.K., Meyer, L.A. (Eds.), Climate Change 2014: Synthesis Report. Contribution of Working Groups I, II and III to the Fifth Assessment Report of the Intergovernmental Panel on Climate Change. IPCC, Geneva, Switzerland (Core Writing Team, 151 pp.).

Jaakkola, K., Saukkoriipi, A., Jokelainen, J., et al., 2014. Decline in temperature and humidity increases the occurrence of influenza in cold climate. Environ. Heal. 13, 22.

Kodra, E., Steinhaeuser, K., Ganguly, A.R., 2011. Persisting cold extremes under twenty first-century warming scenarios. Geophys. Res. Lett. 38, L08705.

Kysely, J., Pokorna, L., Kyncl, J., Kriz, B., 2009. Excess cardiovascular mortality associated with cold spells in the Czech Republic. BMC Public Health 9, 19.

Langford, I.H., Bentham, G., 1995. The potential effects of climate change on winter mortality in England and Wales. Int. J. Biometeorol. 38, 141-147.

León-Gómez, I., Delgado-Sanz, C., Jiménez-Jorge, S., et al., 2015. Exceso de mortalidad relacionado con la gripe en España en el invierno de 2012. Gac. Sanit. 29 (4), 258-265.

Lin, Y.K., Wang, Y.C., Lin, P.L., Li, M.H., Ho, T.J., 2013. Relationships between coldtemperature indices and all causes and cardiopulmonary morbidity and mortality in a subtropical island. Sci. Total Environ. 461-462, 627-635 (Sep 1).

Linares, C., Carmona, R., Díaz, J., 2014. Análisis del impacto a corto plazo de los extremos térmicos y de otros factores ambientales sobre la mortalidad diaria en la ciudad de Madrid en el periodo 2001-2009. Reports I and II Prepared for the European Commission Under the BASE (Bottom-UP Climate Adaptation Strategies Towards a Sustainable Europe) Project, 7th Research Framework Programme Under GA (No. 308,337).

Linares, C., Miron, I.J., Carmona, R., Sanchez, R., Diaz, J., 2015a. Time trend in natural-cause circulatory-cause and respiratory-cause mortality associated with cold waves in Spain, 1975-2008. Stochastic Environmental Research and Risk Assessment (online: 10 October 2015. http://rd.springer.com/article/10.1007\%2Fs00477-015-1169-3).

Linares, C., Diaz, J., Tobias, A., Carmona, R., Miron, I.J., 2015b. Impact of heat and cold waves on circulatory-cause and respiratory-cause mortality in Spain: 1975-2008. Stoch. Env. Res. Risk A. 29 (8), 2037-2046.

López-Cuadrado, T., de Mateo, S., Jiménez-Jorge, S., et al., 2012. Influenza-related mortality in Spain, 1999-2005. Gac. Sanit. 26 (4), 325-329.

Makinen, T.M., Juvonen, R., Jokelainen, J., Harju, T.H., Peitso, A., Bloigu, A., et al., 2009. Cold temperature and low humidity are associated with increased occurrence of respiratory tract infections. Respir. Med. 103 (3), 456-462 (Mar).

Matias, G., Taylor, R., Haguinet, F., Schuck-Paim, C., Lustig, R., Shinde, V., 2014. Estimates of mortality attributable to influenza and RSV in the United States during 1997-2009 by influenza type or subtype, age, cause of death, and risk status. Influenza Other Respir. Viruses 8 (5), 507-515. http://dx.doi.org/10.1111/irv.12258 (PMID: 24975705).

Medina-Ramon, M., Zanobetti, A., Cavanagh, D.P., Schwartz, J., 2006. Extreme temperatures and mortality: assessing effect modification by personal characteristics and specific cause of death in a multi-city case-only analysis. Environ. Health Perspect. 114 (9), 1331-1336 (Sep).

Mercer, J.B., 2003. Cold-an underrated risk factor for health. Environ. Res. 92 (1), 8-13 (May).

Mirón, I.J., Montero, J.C., Criado, J.J., Gutiérrez, G., Paredes, D., Mayoral, S., Linares, C., 2006. Tratamiento y estudio de series de temperatura para su aplicación en salud pública. El caso de Castilla - La Mancha. Rev. Esp. Salud Publica 80, 113-124.

Miron, I.J., Montero, J.C., Criado-Alvarez, J.J., Linares, C., Diaz, J., 2012. Intense cold and mortality in Castile-La Mancha (Spain): study of mortality trigger thresholds from 1975 to 2003. Int. J. Biometeorol. 56 (1), 145-152 (Jan)

Mirón, I.J., Montero, J.C., Criado-Álvarez, J.J., Linares, C., Díaz, J., 2015. Time trends in causespecific mortality during heat waves in Castile-La Mancha: Spain, 1975-2008. Int. J. Biometeorol. 59, 1213-1222.
Monteiro, A., Carvalho, V., Gois, J., Sousa, C., 2013. Use of "Cold Spell” indices to quantify excess chronic obstructive pulmonary disease (COPD) morbidity during winter (November to March 2000-2007): case study in Porto. Int. J. Biometeorol. 57 (6), $857-870$ (Nov)

Montero, J.C., Miron, I.J., Criado-Alvarez, J.J., Linares, C., Diaz, J., 2010. Mortality from cold waves in Castile-La Mancha, Spain. Sci. Total Environ. 408 (23), 5768-5774 (Nov 1).

Montero, J.C., Miron, I.J., Criado-Alvarez, J.J., Linares, C., Diaz, J., 2012. Influence of local factors in the relationship between mortality and heat waves: Castile-La Mancha (19752003). Sci. Total Environ. 414, 73-80 (Jan 1).

Nakai, S., Itoh, T., Marimoto, T., 1999. Deaths from heat-stroke in Japan: 1968-1994. Int. J. Biometeorol. 43, 124-127.

Naughton, M.P., Henderson, A., Mirabelli, M., Kaiser, R., Wilhelm, J.L., Kieszak, S.M., et al., 2002. Heat-related mortality during a 1999 heatwave in Chicago. Am. J. Prev. Med. 22, 221-227.

Ng, C.F., Ueda, K., Takeuchi, A., Nitta, H., Konishi, S., Bagrowicz, R., et al., 2014. Sociogeographic variation in the effects of heat and cold on daily mortality in Japan. J. Epidemiol. 24 (1), 15-24.

Nielsen, J., Mazick, A., Glismann, S., Molbak, K., 2011. Excess mortality related to seasonal influenza and extreme temperatures in Denmark, 1994-2010. BMC Infect. Dis. 11 (1), 350. http://dx.doi.org/10.1186/1471-2334-11-350 (PMID: 22176601).

Prieto, L., Garćía-Herrera, R., Díaz, J., Hernández Tesoa, T., 2004. Minimum extreme temperatures over peninsular Spain. Glob. Planet. Chang. 44, 59-71.

Rizzo, C., Bella, A., Viboud, C., et al., 2007. Trends for influenza-related deaths during pandemic and epidemic seasons, Italy, 1969-2001. Emerg. Infect. Dis. 13 (5), 694-699.

Rocklöv, J., Ebi, K., Forsberg, B., 2011. Mortality related to temperature and persistent extreme temperatures: a study of cause-specific and age-stratified mortality. Occup. Environ. Med. 68 (7), 531-536 (Jul).

Roldán, E., Gómez, M., Pino, M.R., Esteban, M., Díaz, J., 2011. Determinación de zonas isoclimáticas y selección de estaciones meteorológicas representativas en Aragón como base para la estimación del impacto del cambio climático sobre la posible relación entre la mortalidad y temperatura. Rev. Esp. Salud Publica 85, 603-610.

Roldán, E., Gómez, M., Pino, R., Díaz, J., 2014. The impact of extremely high temperatures on mortality and mortality cost. Int. J. Environ. Health Res. http://dx.doi.org/10.1080/ 09603123.2014.938028.

Ryti, N.R., Guo, Y., Jaakkola, J.J., 2015. Global association of cold spells and adverse health effects: a systematic review and meta-analysis. Environ. Health Perspect. http://dx. doi.org/10.1289/ehp.1408104 (May 15)

Rytkonen, M., Raatikka, V.P., Nayha, S., Hassi, J., 2005. Exposure to cold and the symptoms thereof. Duodecim 121 (4), 419-423.

Sterne, J.A.C., 2009. Meta-analysis in Stata: An Updated Collection From the Stata Journal. Stata Press 978-1-59718-049-8.

The Eurowinter Group, 1997. Cold exposure and winter mortality from ischaemic heart disease, cerebrovascular disease, respiratory disease, and all causes in warm and cold regions of Europe. Lancet 349 (9062), 1341-1346 (May 10).

Thompson, W.W., Moore, M.R., Weintraub, E., et al., 2009. Estimating influenza-associated deaths in the United States. Am. J. Public Health 99 (Suppl. 2), S225-S230.

Tong, S., Whang, X.Y., Burnett, A.G., 2010. Assessment of heat-related health impacts in Brisbane, Australia: comparison of different heatwave definitions. PLoS One 5 (8), e12155. http://dx.doi.org/10.1371/journal.pone.0012155.

Urban, A., Davidkovova, H., Kysely, J., 2014 Aug. Heat- and cold-stress effects on cardiovascular mortality and morbidity among urban and rural populations in the Czech Republic. Int. J. Biometeorol. 58 (6), 1057-1068.

Vandentorren, S., Bretin, P., Zeghnoun, A., Mandereau-Bruno, L., Croisier, A., Cochet, C., et al., 2006. August 2003 heat wave in France: risk factors for death of elderly people living at home. Eur. J. Pub. Health 16, 583-591.

Vardoulakis, S., Dear, K., Hajat, S., Heaviside, C., Eggen, B., McMichael, A.J., 2014 Dec. Comparative assessment of the effects of climate change on heat- and cold-related mortality in the United Kingdom and Australia. Environ. Health Perspect. 122 (12), 1285-1292.

Wang, Y.C., Lin, Y.K., Chuang, C.Y., Li, M.H., Chou, C.H., Liao, C.H., et al., 2012. Associating emergency room visits with first and prolonged extreme temperature event in Taiwan: a population-based cohort study. Sci. Total Environ. 416, 97-104.

Wang, C., Chen, R., Kuang, X., Duan, X., Kan, H., 2014. Temperature and daily mortality in Suzhou, China: a time series analysis. Sci. Total Environ. 466-467, 985-990 (Jan 1).

WHO, 2007. Protecting Health in Europe From Climate Change. World Health Organization WHO/EUROPE, Geneva.

WHO, 2014. Influenza (Seasonal) Fact Sheet $N^{\circ} 211$ (March).

Wu, W., Xiao, Y., Li, G., Zeng, W., Lin, H., Rutherford, S., et al., 2013. Temperature-mortality relationship in four subtropical Chinese cities: a time-series study using a distributed lag non-linear model. Sci. Total Environ. 449, 355-362 (Apr 1).

Xie, H., Yao, Z., Zhang, Y., Xu, Y., Xu, X., Liu, T., et al., 2013. Short-term effects of the 2008 cold spell on mortality in three subtropical cities in Guangdong Province, China. Environ. Health Perspect. 121 (2), 210-216 (Feb).

Zanobetti, A., O'Neill, M.S., Gronlund, C.J., Schwartz, J.D., 2013. Susceptibility to mortality in weather extremes: effect modification by personal and small-area characteristics. Epidemiology 24 (6), 809-819 (Nov). 